\title{
FAKTOR-FAKTOR YANG BERHUBUNGAN DENGAN KEJADIAN OBESITAS PADA IBU RUMAH TANGGA DI DESA TIBANG BANDA ACEH
}

\section{Factors That Are Related To The Event Of Obesity In The Households In Household In Tibang Village, Banda Aceh City}

\author{
Mira Abdullah"1, Dhea ananda ${ }^{2}$ \\ ${ }^{1,2}$ Fakultas Ilmu Kesehatan, Universitas Ubudiyah Indonesia, Banda Aceh \\ Email: miraabdullah@uui.ac.id"1 ${ }^{* 1}$ dhea.ananda@gmail.com²
}

\begin{abstract}
Abstrak
Obesitas terjadi karena tidak seimbangnya energi antara kalori yang dikonsumsi dan kalori yang digunakan. Bila energi yang masuk berlebihan dan tidak diimbangi dengan aktivitas fisik yang seimbang akan memudahkan seseorang menjadi obesitas. Ibu rumah tangga pengguna kontrasepsi hormonal juga dapat menyebabkan obesitas. Mengetahui hubungan asupan makanan, aktivitas fisik, penggunaan alat kontrasepsi dengan kejadian obesitas pada ibu rumah tangga di Desa Tibang Banda Aceh Tahun 2018. Penelitian bersifat analitik dengan desain cross sectional. Pengambilan sampel menggunakan tehnik simple random sampling dengan jumlah 81 responden. Pengumpulan data dilakukan pada ibu rumah tangga di Desa Tibang Banda Aceh, dengan membagikan kuesioner, selanjutnya dilakukan uji chi-square dengan tingkat kepercayaan $95 \%$ dan batas kemaknaan $(\alpha=0,05)$ Ha diterima $p$ value $<0,05$. Analisa univariat didapat dari 81 responden yang mengalami obesitas 52 orang $(62,4 \%)$, energi lebih 43 orang $(53,1 \%)$, karbohidrat lebih 44 orang $(54,3 \%)$, protein cukup 42 orang $(51,9 \%)$, lemak lebih 34 orang $(42,0 \%)$. Analisa bivariat terdapat asupan energi $(\mathrm{p}=0,000)$, karbohidrat $(\mathrm{p}=0,000)$, protein $(\mathrm{p}=0,000)$, lemak $(\mathrm{p}=0,000)$, aktivitas fisik $(\mathrm{p}=0,001)$ dan penggunaan alat kontrasepsi $(\mathrm{p}=0,001)$. Ada hubungan asupan makanan dengan kejadian obesitas $(\mathrm{p}=0,000)$, ada hubungan aktivitas fisik dan penggunaan alat kontrasepsi dengan kejadian obesitas $(\mathrm{p}=0,001)$ pada pada ibu rumah tangga di Desa Tibang Banda Aceh. Diharapkan para ibu rumah tangga agar dapat menyesuaikan asupan makanan yang dikonsumsi dengan aktivitas yang dilakukan dan pihak Puskesmas mengadakan kegiatan penanggulangan obesitas, misalnya senam kesehatan jasmani/ jantung sehat secara rutin (seminggu sekali)
\end{abstract}

\section{Kata kunci : asupan makanan, aktivitas fisik, penggunaan kontrasepsi, obesitas}

\begin{abstract}
Obesity occurs due to energy imbalance between the calories consumed and the calories used. If the incoming energy is excessive and not balanced with balanced physical activity will make it easier for someone to become obese. Housewives who use hormonal contraception can also cause obesity. Knowing the relationship of food intake, physical activity, use of contraceptives with the incidence of obesity in housewives in Tibang Village Banda Aceh in 2018. The research was analytic with cross sectional design. Sampling using simple random sampling technique with 81 respondents. Data collection was carried out to housewives in Tibang Village, Banda Aceh, by distributing questionnaires, then the chi-square test was conducted with a 95\% confidence level and significance limit $(\alpha=0.05)$ Ha accepted $p$ value $<0.05$. Univariate analysis was obtained from 81 respondents who were obese 52 people (62.4\%),
\end{abstract}


Journal of Healthcare Technology and Medicine Vol. 5 No. 1 April 2019

Universitas Ubudiyah Indonesia

e-ISSN : 2615-109X

over 43 people energy (53.1\%), carbohydrates over 44 people (54.3\%), enough protein 42 people (51.9\%) fat over 34 people (42.0\%). Bivariate analysis included energy intake ( $p=$ $0,000)$, carbohydrates $(p=0,000)$, protein $(p=0,000)$, fat $(p=0,000)$, physical activity $(p=$ $0.001)$ and the use of contraceptives $(p=0.001)$. There is a relationship between food intake and obesity $(p=0,000)$, there is a relationship between physical activity and contraceptive use and obesity $(p=0.001)$ among housewives in Tibang Banda Aceh Village. It is expected that housewives can adjust the intake of food consumed with the activities carried out and the Health Center conducts obesity prevention activities, for example physical health / heart health exercises regularly (once a week)

\section{Keywords: food intake, physical activity, contraceptive use, obesity}

\section{PENDAHULUAN}

Indonesia saat ini mengalami permasalahan gizi ganda, ketika permasalahan gizi kurang belum terselesaikan, muncul permasalahan gizi lebih. Gizi lebih atau obesitas dianggap sebagai sinyal awal, munculnya penyakit- penyakit degeneratif yang saat ini merambah seluruh pelosok Indonesia. Tingginya prevalensi obesitas, hipertensi, dislipidemi dan penyakit degeneratif lainnya, menyebabkan tingginya angka kejadian penyakit dan angka kematian di Indonesia (Waspadji, 2010).

Di Aceh sendiri prevalensi obesitas pada wanita dewasa masih cukup tinggi yaitu 52,4\% dengan kategori (Gemuk 16\% kategori Obesitas 36,4\%) dan Di Nagan Raya prevalensi obesitas masih cukup tinggi yaitu sebesar 47,7\% (Gemuk 15,2\% Obesitas 32,5\%) (Dinas Kesehatan Aceh 2017).

Beberapa faktor risiko yang menyebabkan terjadi obesitas pada wanita dewasa menurut penelitian Diana tahun 2013 yaitu status perkawinan, pendapatan rumah tangga, aktivitas fisik serta asupan energi dan karbohidrat. Selain itu, faktor genetik, faktor psikologis, pola hidup yang kurang tepat, kebiasaan makan yang salah, stres dan faktor pemicu lain. Menurut penelitian Sikalak, Widajanti, dan Aruben.pada tahun 2017 Obesitas juga disebabkan oleh beberapa faktor, antara lain: genetik, asupan energi, aktivitas fisik, lingkungan, psikis, status sosial ekonomi dan penggunaan kontrasepsi khususnya kontrasepsi hormonal.

Penelitian Salim (2014) menunjukkan bahwa ada hubungan penggunaan alat kontrasepsi dengan kejadian obesitas pada karyawati Sekretariat Daerah Kabupaten Wonosobo ( $\mathrm{p}$ value $=0,030$ ). Kontrasepsi hormonal (suntikan, pil dan implan) dapat menaikan berat badan secara perlahan-lahan pada wanita yang menggunakannya. Penggunaan alat kontrasepsi hormonal mempunyai kecenderungan terhadap obesitas 
Journal of Healthcare Technology and Medicine Vol. 5 No. 1 April 2019

Universitas Ubudiyah Indonesia

e-ISSN : 2615-109X

dibandingkan dengan yang tidak menggunakan kontrasepsi hormonal.

Ibu rumah tangga yang mengalami obesitas sebagian besar menggunakan kontrasepsi hormonal, terlebih pada ibu yang menggunakan suntikan 3 bulan, ibu mengatakan berat badannya semakin hari semakin bertambah dan juga beberapa responden mengeluhkan nafsu makan yang meningkat setelah menggunakan suntikan 3 bulan tersebut, namun mereka menyadari selain faktor kontrasepsi, kurangnya aktivitas fisik yang berat dan hanya cenderung melakukan pekerjaan rutin rumah tangga lah yang menjadi salah satu penyebab kenaikan berat badan yang mereka alami (Hartanto, 2002).

\section{METODE PENELITIAN}

Jenis penelitian ini adalah penelitian yang bersifat analitik dengan menggunakan desain cross sectional yaitu waktu pengukuran atau observasi data variabel independen dan dependen hanya pada satu waktu. Dalam penelitian ini peneliti ingin melihat faktor-faktor yang berhubungan dengan kejadian Obesitas pada ibu rumah tangga di Desa Tibang Banda Aceh. Penelitian ini telah dilakukan di Desa Tibang Banda Aceh pada tanggal 10 Oktober sampai dengan 8 November 2016. Populasi dalam penelitian ini adalah ibu rumah tangga yang berjumlah 428 Ibu Rumah Tangga yang berada di Desa Tibang Banda Aceh.

Sampel dalam penelitian ini adalah 81 orang ibu rumah tangga. Sampel diambil dengan kriteria sebagai berikut :

a. Kriteria Ekslusi

1) Tidak sedang hamil

2) Tidak menderita penyakit tertentu (Ginjal yang akan mengakibatkan penimbunan cairan pada tubuh sering disebut udem).

b. Kriteria Inklusi

Kriteria ekslusi penelitian ini adalah wanita ibu rumah tangga yang berusia dari 20-45 tahun, yang bersedia menjadi sampel dan dapat ditemui dalam jangka waktu penelitian.

1. Identitas sampel

Data identitas sampel diperoleh dengan metode wawancara langsung kepada sampel menggunakan kuesioner yang meliputi data nama, umur, jenis kelamin, tingkat pendidikan, dan alamat.

2. Antropometri

Data antropometri yang dikumpulkan adalah data berat badan dan tinggi 
Journal of Healthcare Technology and Medicine Vol. 5 No. 1 April 2019

Universitas Ubudiyah Indonesia

e-ISSN : 2615-109X

badan. Berat badan diukur menggunakan timbangan injak digital dengan kapasitas $150 \mathrm{~kg}$ dan ketelitian $0,1 \mathrm{~kg}$. Sedangkan tinggi badan diukur menggunakan microtoice dengan kapasitas $200 \mathrm{~cm}$ dan ketelitian $0,1 \mathrm{~cm}$.

3. Data asupan makan

Data asupan makan meliputi asupan energi, asupan protein, asupan lemak dan asupan karbohidrat diperoleh dengan menggunakan metode food recall.

4. Data aktifitas fisik

Data aktivitas fisik diperoleh dengan cara sampel mengisi kuesioner aktivitas fisik yang dilakukan selama 2 x 24 jam.

5. Data alat kontrasepsi

Data penggunaan alat kontrasepsi diperoleh melalui wawancara langsung dengan sampel menggunakan lembar kuesioner.

\section{HASIL DAN PEMBAHASAN}

Penelitian ini dilakukan di Desa Tibang Banda Aceh pada tanggal 10 Oktober -8 November 2016, dengan jumlah responden 81 orang. Pengumpulan data dilakukan dengan cara membagikan kuesioner, maka diperoleh hasil sebagai berikut :

Tabel 1

Distribusi Frekuensi Variabel Pada Ibu Rumah Tangga Di Desa Tibang Banda Aceh

\begin{tabular}{llcc}
\hline No & \multicolumn{1}{c}{ Variabel Penelitian } & f & Persentase \\
\hline 1 & Obesitas & & \\
& a. Tidak Obesitas & 29 & 35,8 \\
& b. Obesitas & 52 & 64,2 \\
\hline 2 & Asupan Makanan & & \\
& a. Energi & 11 & 13,6 \\
& 1) Kurang & 27 & 33,3 \\
& 2) Cukup & 43 & 53,1 \\
& 3) Lebih & & \\
\hline
\end{tabular}

b. Karbohidrat
1) Kurang 9
11,1
2) Cukup
28
34,6
3) Lebih
44
54,3 
Journal of Healthcare Technology and Medicine Vol. 5 No. 1 April 2019

Universitas Ubudiyah Indonesia

e-ISSN : 2615-109X

\section{c. Protein}

$\begin{array}{lll}\text { 1) Kurang } & 25 & 30,9 \\ \text { 2) Cukup } & 42 & 51,9 \\ \text { 3) Lebih } & 14 & 17,3\end{array}$

\section{d. Lemak}

1) Kurang $\quad 17 \quad 21,0$

2) Cukup $30 \quad 37,0$

3) Lebih $34 \quad 42,0$

$3 \quad$ Aktivitas Fisik
a. Ringan
45
55,6
b. Sedang
27
33,3
c. Berat
9
11,3

$4 \quad$ Alat Kontrasepsi

a. Tidak menggunakan 9

kontrasepsi

b. Kontrasepsi nonhormonal 16

c. Kontrasepsi hormonal 56

Tabel 2

Hubungan Asupan Energi Dengan Kejadian Obesitas Pada Ibu Rumah Tangga Di Desa Tibang Kota Banda Aceh

\begin{tabular}{|c|c|c|c|c|c|c|c|}
\hline \multirow{3}{*}{$\begin{array}{r}\text { Asupan } \\
\text { Energi }\end{array}$} & \multicolumn{4}{|c|}{ Obesitas } & \multirow{2}{*}{\multicolumn{2}{|c|}{ Total }} & \multirow[b]{2}{*}{$p$ value } \\
\hline & \multicolumn{2}{|c|}{ Obesitas } & \multicolumn{2}{|c|}{$\begin{array}{c}\text { Tidak } \\
\text { Obesitas }\end{array}$} & & & \\
\hline & $\mathrm{f}$ & $\%$ & f & $\%$ & $\mathrm{f}$ & $\%$ & \\
\hline Kurang & 0 & 0,0 & 11 & 100,0 & 11 & 100 & \\
\hline Cukup & 17 & 63,0 & 10 & 37,0 & 27 & 100 & 0,000 \\
\hline Lebih & 35 & 81,4 & 8 & 18,6 & 43 & 100 & \\
\hline
\end{tabular}

Berdasarkan tabel 1 menunjukkan bahwa dari 81 responden sebagian besar mengalami obesitas yaitu sebanyak 52 responden $(64,2 \%)$, memperoleh asupan makanan dengan kandungan energi pada kategori lebih yaitu sebanyak 43 responden $(53,1 \%)$, kandungan karbohidrat pada kategori lebih yaitu sebanyak 44 responden $(54,3 \%)$, 
Journal of Healthcare Technology and Medicine Vol. 5 No. 1 April 2019

Universitas Ubudiyah Indonesia

e-ISSN : 2615-109X

kandungan protein pada kategori cukup yaitu sebanyak 42 responden $(51,9 \%)$ dan kandungan lemak pada kategori lebih yaitu sebanyak 34 responden (42\%) aktivitas fisik sebagian besar berada pada kategori ringan yaitu sebanyak 45 responden $(55,6 \%)$ dan penggunaan alat kontrasepsi mayoritas hormonal sebanyak 56 responden $(69,1 \%)$.

Berdasarkan tabel 2 menunjukkan bahwa dari 43 responden yang asupan energi lebih mengalami obesitas sebanyak 35 responden $(81,4 \%)$, dari 27 responden yang asupan energi cukup mengalami obesitas sebanyak 17 responden (63\%) dan dari 11 responden yang asupan energi kurang tidak ada yang mengalami obesitas.

Hasil uji statistik diperoleh $p$ value $=0,000<0,05$. Sehingga dapat disimpulkan bahwa ada hubungan asupan energi dengan kejadian obesitas pada ibu rumah tangga di Desa Tibang Banda Aceh.

Tabel 3

Hubungan Asupan Karbohidrat Dengan Kejadian Obesitas Pada Ibu Rumah Tangga Di Desa Tibang Banda Aceh

\begin{tabular}{lccccccc}
\hline $\begin{array}{c}\text { Asupan } \\
\text { Karbohidrat }\end{array}$ & Obesitas & $\begin{array}{c}\text { Obesitas } \\
\text { Tidak } \\
\end{array}$ & \multicolumn{7}{c}{ Obesitas } & Total & $p$ value \\
& $\mathrm{f}$ & $\%$ & $\mathrm{f}$ & $\%$ & $\mathrm{f}$ & $\%$ & \\
Kurang & 0 & 0,0 & 9 & 100,0 & 9 & 100 & \\
Cukup & 16 & 57,1 & 12 & 42,9 & 28 & 100 & 0,000 \\
Lebih & 36 & 81,1 & 8 & 18,2 & 44 & 100 & \\
\hline
\end{tabular}

Berdasarkan tabel 4.3 menunjukkan bahwa dari 44 responden yang asupan karbohidrat lebih mengalami obesitas sebanyak 36 responden (81,1\%), dari 28 responden yang asupan karbohidrat cukup mengalami obesitas sebanyak 16 responden $(57,1 \%)$ dan dari 9 responden yang asupan karbohidrat kurang tidak ada yang mengalami obesitas.

Hasil uji statistik diperoleh $p$ value $=0,000<0,05$. Sehingga dapat disimpulkan bahwa ada hubungan asupan karbohidrat dengan kejadian obesitas pada ibu rumah tangga di Desa Tibang Kota Banda Aceh. 
Journal of Healthcare Technology and Medicine Vol. 5 No. 1 April 2019

Universitas Ubudiyah Indonesia

e-ISSN : 2615-109X

\section{Tabel 4}

Hubungan Asupan Protein Dengan Kejadian Obesitas Pada Ibu Rumah Tangga Di Desa Tibang Banda Aceh

\begin{tabular}{|c|c|c|c|c|c|c|c|}
\hline \multirow{3}{*}{$\begin{array}{l}\text { Asupan } \\
\text { Protein }\end{array}$} & \multicolumn{4}{|c|}{ Obesitas } & \multirow{2}{*}{\multicolumn{2}{|c|}{ Total }} & \multirow[b]{2}{*}{$p$ value } \\
\hline & \multicolumn{2}{|c|}{ Obesitas } & \multicolumn{2}{|c|}{$\begin{array}{c}\text { Tidak } \\
\text { Obesitas }\end{array}$} & & & \\
\hline & $f$ & $\%$ & $\mathrm{f}$ & $\%$ & $f$ & $\%$ & \\
\hline Kurang & 7 & 28,0 & 18 & 72,0 & 25 & 100 & \\
\hline Cukup & 34 & 81,0 & 8 & 19,0 & 42 & 100 & 0,000 \\
\hline Lebih & 11 & 78,6 & 3 & 21,4 & 14 & 100 & \\
\hline
\end{tabular}

Berdasarkan tabel 4.4 menunjukkan bahwa dari 42 responden yang asupan protein cukup mengalami obesitas sebanyak 34 responden (81\%), dari 14 responden yang asupan protein lebih mengalami obesitas sebanyak 11 responden $(78,6 \%)$ dan dari 25 responden yang asupan protein kurang mengalami obesitas sebanyak 7 responden (28\%)

Hasil uji statistik diperoleh $p$ value $=0,000<0,05$. Sehingga dapat disimpulkan bahwa ada hubungan asupan protein dengan kejadian obesitas pada ibu rumah tangga di Desa Tibang Banda Aceh.

Tabel 5

Hubungan Asupan Lemak Dengan Kejadian Obesitas Pada Ibu Rumah Tangga Di Desa Tibang Banda Aceh

\begin{tabular}{|c|c|c|c|c|c|c|c|}
\hline \multirow{3}{*}{$\begin{array}{r}\text { Asupan } \\
\text { Lemak }\end{array}$} & \multicolumn{4}{|c|}{ Obesitas } & \multirow{2}{*}{\multicolumn{2}{|c|}{ Total }} & \multirow[b]{2}{*}{$p$ value } \\
\hline & \multicolumn{2}{|c|}{ Obesitas } & \multicolumn{2}{|c|}{$\begin{array}{c}\text { Tidak } \\
\text { Obesitas }\end{array}$} & & & \\
\hline & $f$ & $\%$ & $f$ & $\%$ & $f$ & $\%$ & \\
\hline Kurang & 0 & 0,0 & 17 & 100,0 & 17 & 100 & \\
\hline Cukup & 19 & 63,3 & 11 & 36,7 & 30 & 100 & 0,000 \\
\hline Lebih & 33 & 97,1 & 1 & 2,9 & 34 & 100 & \\
\hline
\end{tabular}

Berdasarkan tabel 4.5 menunjukkan bahwa dari 34 responden yang asupan lemak lebih mengalami obesitas sebanyak 33 responden $(97,1 \%)$, dari 30 responden yang asupan lemak cukup mengalami obesitas sebanyak 19 responden $(63,3 \%)$ dan dari 17 responden yang asupan lemak kurang tidak ada yang mengalami obesitas.

Hasil uji statistik diperoleh $p$ value $=0,000<0,05$. Sehingga dapat disimpulkan bahwa ada hubungan asupan lemak dengan kejadian obesitas pada ibu rumah tangga di Desa Tibang Banda Aceh. 
Journal of Healthcare Technology and Medicine Vol. 5 No. 1 April 2019

Universitas Ubudiyah Indonesia

e-ISSN : 2615-109X

\section{Tabel 6}

Hubungan Aktivitas Fisik Dengan Kejadian Obesitas Pada Ibu Rumah Tangga Di Desa Tibang Banda Aceh

\begin{tabular}{|c|c|c|c|c|c|c|c|}
\hline \multirow{3}{*}{$\begin{array}{c}\text { Aktivitas } \\
\text { Fisik }\end{array}$} & \multicolumn{4}{|c|}{ Obesitas } & \multirow{2}{*}{\multicolumn{2}{|c|}{ Total }} & \multirow[b]{2}{*}{$p$ value } \\
\hline & \multicolumn{2}{|c|}{ Obesitas } & \multicolumn{2}{|c|}{$\begin{array}{c}\text { Tidak } \\
\text { Obesitas }\end{array}$} & & & \\
\hline & $\mathrm{f}$ & $\%$ & $f$ & $\%$ & $f$ & $\%$ & \\
\hline Ringan & 39 & 86,7 & 6 & 13,3 & 45 & 100 & \\
\hline Sedang & 13 & 48,1 & 14 & 51,9 & 27 & 100 & 0,001 \\
\hline Berat & 0 & 0,0 & 9 & 100,0 & 9 & 100 & \\
\hline
\end{tabular}

Berdasarkan tabel 4.6 menunjukkan bahwa dari 45 responden yang memiliki aktivitas fisik ringan mengalami obesitas sebanyak 39 responden (86,7\%), dari 27 responden yang memiliki aktivitas fisik sedang mengalami obesitas sebanyak 13 responden $(48,1 \%)$ dan dari 9 responden yang memiliki aktivitas fisik berat tidak ada yang mengalami obesitas.

Hasil uji statistik diperoleh $p$ value $=0,001<0,05$. Sehingga dapat disimpulkan bahwa ada hubungan aktivitas fisik dengan kejadian obesitas pada ibu rumah tangga di Desa Tibang Banda Aceh.

Tabel 7

Hubungan Alat Kontrasepsi Dengan Kejadian Obesitas Pada Ibu Rumah Tangga Di Desa Tibang Banda Aceh

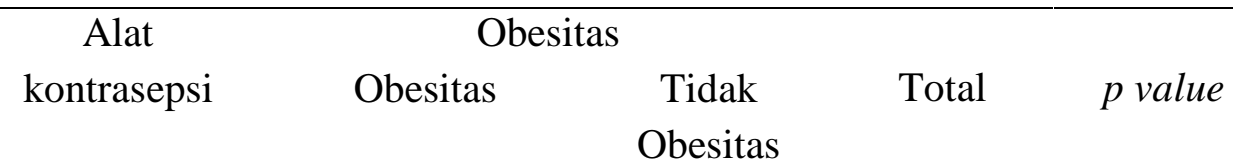


Journal of Healthcare Technology and Medicine Vol. 5 No. 1 April 2019

Universitas Ubudiyah Indonesia

e-ISSN : 2615-109X

\begin{tabular}{lccccccc}
\hline & $\mathrm{f}$ & $\%$ & $\mathrm{~F}$ & $\%$ & $\mathrm{f}$ & $\%$ & \\
\cline { 2 - 6 } Tidak & 2 & 22,2 & 7 & 77,8 & 9 & 100 & \\
menggunakan & & & & & & & 0,001 \\
$\begin{array}{l}\text { Nonhormonal } \\
\text { Hormonal }\end{array}$ & 4 & 18,8 & 13 & 81,2 & 16 & 100 & \\
\hline
\end{tabular}

Berdasarkan tabel 4.7 menunjukkan bahwa dari 56 responden yang menggunakan kontasepsi hormonal mengalami obesitas sebanyak 47 responden $(83,7 \%)$, dari 16 responden yang menggunakan kontasepsi nonhormonal mengalami obesitas sebanyak 3 responden (18,8\%) dan dari 9 responden yang tidak menggunakan kontasepsi mengalami obesitas sebanyak 2 responden $(22,2 \%)$.

Hasil uji statistik diperoleh $p$ value $=0,001<0,05$. Sehingga dapat disimpulkan bahwa ada hubungan penggunaan alat kontrasepsi dengan kejadian obesitas pada ibu rumah tangga di desa Tibang Banda Aceh.

\section{KESIMPULAN}

1. Ada hubungan asupan energi $(\mathrm{p}=0,000)$, karbohidrat $(\mathrm{p}=0,000)$, protein $(\mathrm{p}=0,000)$ dan lemak $(\mathrm{p}=0,000)$ dengan kejadian obesitas pada ibu rumah tangga di Desa Tibang Kecamatan Banda Aceh Tahun

2. Ada hubungan aktivitas fisik dengan dengan kejadian obesitas pada ibu rumah tangga di di Desa Tibang Banda Aceh ( $p$ value $=0,001)$.

3. Ada hubungan penggunaan alat kontrasepsi dengan dengan kejadian obesitas pada ibu rumah tangga di di Desa Tibang Kota Banda Aceh ( $p$ value $=0,001$ )

\section{DAFTAR PUSTAKA}

Afriansyah. 2010. Faktor-Faktor yang Behubungan dengan Kejadian Obesitas Pada Ibu Rumah Tangga di Desa Biluy Kabupaten Aceh Besar. Poltekkes Kemenkes Aceh. Action Journal, Volume 1, Nomor 2, November 2016. Almatsier, S. 2009. Prinsip Dasar Ilmu Gizi. Jakarta : PT Gramedia Pustaka Apriaty. 2015. Faktor Resiko Obesitas Ibu Rumah Tangga di Kelurahan Bendungan, Kecamatan Bina Pustaka.

Gajah Mungkur, Kota Semarang Universitas Diponegoro Semarang.

Diana, 2013. Faktor Risiko Kegemukan Pada Wanita Dewasa Indonesia. J Gizi dan Pangan. $8(1): 1-8$.

Gibney, M. J. 2007 Gizi Kesehatan Masyarakat, Jakarta, Buku Kedokteran EGC Hartanto. 2002. KB Keluarga Berencana dan Kontrasepsi. Jakarta Pustaka Sinar. Hartanto. 
Journal of Healthcare Technology and Medicine Vol. 5 No. 1 April 2019

Universitas Ubudiyah Indonesia

e-ISSN : 2615-109X

2004. Keluarga Berencana dan Kontrasepsi. Pustaka Sinar Mandiri Jakarta.

Kecamatan Tallo Kota Makassar. Jurnal Media Gizi Pangan, vol X, ed

Makara Kesehatan. 15(1), 37-43

Manuaba. 2010. Ilmu Kebidanan Penyakit Kandungan dan KB. Jakarta EGC. Mustamin. 2010.

Asupan Energi dan Aktivitas Fisik dengan Kejadian Obesitas

Murray, R. K. Granner. 2009. Biokimia Harper. Jakarta : EGC Nasedul,

H. 2008. Sehat Itu Murah, PT. Kompas Media. Jakarta

Notoatmodjo, S. 2010. Metodologi Penelitian Kesehatan, Rineka Cipta Jakarta.

Notoatmodjo, S. 2003. Pendidikan dan Perilaku Kesehatan. Jakarta, Rineka Cipta.

Novitasary. 2013. Hubungan Asupan Gizi Makro dan Aktivitas Fisik dengan Kejadian Obesitas Pada Wanita Usia Subur (WUS) Peserta Jamkesmas Di Puskesmas Wawonasa Kecamatan Singkil Manado. Jurnal e-Biomedik (eBm) Vol 1 No 1 Maret 2013. Hal 607613, universitas Sam Ratulangi Manado

Nuryanto, 2015 Hubungan Lingkar Pinggang, Asupan Zat Gizi, dan Aktivitas Fisik Dengan Kepadatan Tulang Pada Wanita Usia 30-50 Tahun. Journal of Nutrition College, Volume 4, Nomor 1, Tahun 2015, Halaman 89 - 95 Online di : http://ejournals1.undip.ac.id/index.php/jnc

Purwati. 2005. Perencanaan Menu Untuk Penderita Kegemukan. Jakarta : PT Swadaya Sartika. (2011). Faktor risiko Obesitas Pada Ibu Rumah Tangga di Indonesia. Sentral Pada Ibu Rumah Tangga di Kelurahan Ujung Pandang Baru Utama. 